\title{
Новые эпизоды творческой биографии И.В. Жолтовского
}

\author{
И.Е.Печенкин, НИИТИАГ, РГГУ, Москва \\ О.С.Шурыгина, Москва
}

В статье изложены некоторые результаты исследования творческой биографии И.В. Жолтовского периода 1900-1910-х годов. Несмотря на наличие солидной библиографии о Жолтовском, он остаётся фигурой по большей части загадочной. Авторы статьи сосредоточили внимание на трёх сюжетах. Во-первых, используя материалы архивных и музейных фондов, авторы смогли уточнить некоторые детали, связанные с обучением архитектора в Императорской Академии художеств и началом его самостоятельной карьеры. Второй сюжет касается списка дореволюционных работ Жолтовского, который должен быть дополнен по итогам исследований, выявивших практически забытые произведения архитектора - дом в усадьбе Щурово и проект Русского павильона на выставке в Риме 1911 года. По неизвестным причинам, они не фигурировали даже в перечнях проектов и построек, составленных при жизни Жолтовского, хотя по источникам авторство его атрибутируется достаточно твёрдо. Наконец, авторам удалось прояснить роль Жолтовского в создании перевода «Четырёх книг об архитектуре» А. Палладио. История создания этого перевода прежде специально не изучалась. Как показывают авторы, место Жолтовского в этой истории было иным, чем принято думать.

Ключевые слова: архитектура XX века, русская архитектура, биография, архивные исследования, неоклассицизм, палладианство, архитектурные трактаты, И.В. Жолтовский.

\section{Some New Episodes from I.V. Zholtovsky's Creative Biography \\ I.E.Pechenkin, NIITIAG, RSUH, Moscow \\ 0.S.Shurygina, Moscow}

The article consists of some results of research on architect Ivan Zholtovsky's biography in 1900-1910s. Despite a huge bibliography, this person is still a mysterious one. The authors of the article focused the attention on three plots. Firstly, using archival sources and museum funds, the authors succeeded to clarify some details related to Zholtovsky's education at the Imperial Academy of Arts as well as to the beginning of his independent career. The second story concerns the list of pre-revolutionary works of Zholtovsky, which should be supplemented by the results of the research that revealed nearly forgotten pieces - the house in the Shchurovo estate and the design of the Russian pavilion for the exhibition in Rome in 1911. For unknown reasons, they did not appear even in the lists of projects and buildings made during Zholtovsky's lifetime, although the sources attribute his authorship quite firmly. Finally, the authors managed to describe the role of Zholtovsky in creating the translation of Palladio's "Four Books on Architecture". The genesis of this translation has never been specifically studied before. As the authors show, Zholtovsky's participation in that process was different from what is commonly thought.

Keywords: 20th-century architecture, Russian architecture, biography, archival studies, neoclassicism, Palladianism, architectural treatises, Ivan Zholtovsky.

Имя Ивана Владиславовича Жолтовского (1867-1959) (рис. 1) относится к разряду наиболее значимых для отечественной архитектуры. Объясняется это не только числом и

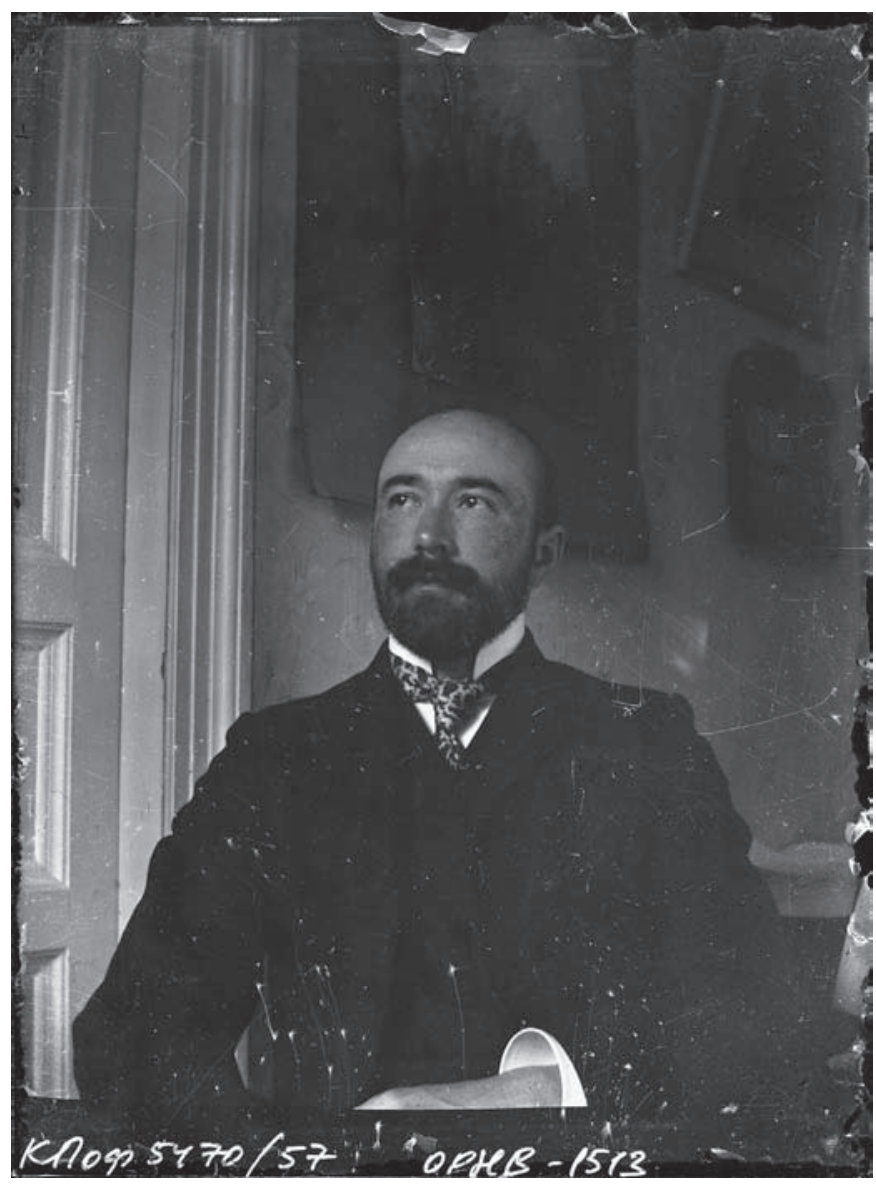

Рис. 1. Портрет И.В. Жолтовского. Фото 1900-х годов [источник: Государственный научно-исследовательский музей архитектуры им. А.В. Щусева, Москва (ГНИМА)] 
качеством его работ как зодчего-практика, но и запечатлённым в литературе и живой памяти младших современников образом патриарха профессии, глубокого педагога и интеллектуала, как бы связавшего советскую архитектуру с эпохой итальянского Возрождения, фактически собеседника великих творцов XVI века. Знаменитая фраза Корнея Чуковского («в России надо жить долго!» [1, с. 42]) может быть отнесена и к Жолтовскому - последнему из академистов XIX столетия, завершившему жизненный путь в годы развёртывания в стране массового панельного домостроения.

Как и любого художника, рассматривать Жолтовского можно в нескольких разных контекстах. Спешим предуведомить читателя, что в данной статье мы не анализируем теоретические соображения Ивана Владиславовича, не говорим о принципах архитектурной композиции, о его творческом методе или педагогической системе, не анализируем его произведения. Изучение этих аспектов - отдельная благородная задача, тем более сложная, что Жолтовский не оставил ни одного текста, в котором была бы систематически изложена его творческая концепция. Исследователям приходится реконструировать его взгляды по свидетельствам третьих лиц ${ }^{1}$. Мы же определяем наше поле исследования в связи с биографической фактологией, в которую входит и описание творческого наследия.

0 Жолтовском было написано немало, начало этой библиографии положили ещё прижизненные издания [3]. В диссертации А.В. Фирсовой [4] и монографических трудах, созданных С.0. Хан-Магомедовым [5] и Д.С. Хмельницким [6], раннему периоду жизни и творчества Жолтовского обычно уделялось совсем немного места в соответствии с его репутацией в первую очередь советского зодчего ${ }^{2}$. Исключением являются публикации М.В. Нащокиной [7; 8], однако начатые ею исследования, несомненно, заслуживают развития и углубления. Недавний полуторавековой юбилей мастера предоставил возможность не только помянуть его добрым словом $[9 ; 10]$, но и непредвзято оценить актуальное состояние научного знания о Жолтовском³. В небольшой книге, написанной и изданной авторами этой статьи в 2017 году [14], была предпринята попытка детализации раннего этапа биографии Ивана Владиславовича и уточнения списка его работ, который имеет ряд несовпадающих друг с другом редакций 4 .
Очевидно, что к сегодняшнему дню мы имеем изрядное количество недосказанностей, связанных с фигурой Жолтовского. «Вокруг имени И.В. Жолтовского всё ещё создаются легенды», - эти слова А.Г. Габричевского ${ }^{5}$, несостоявшегося первого биографа Ивана Владиславовича, продолжают быть актуальными и в 2020 году.

Из академического личного дела И.В. Жолтовского следует, что учёба его шла отнюдь не гладко, несколько раз он бывал отчислен из Академии и в 1898 году, спустя одиннадцать лет со дня поступления, вышел из этого учебного заведения без диплома и звания архитектора-художника по причине задолженностей по строительной механике и некоторым другим «практическим» предметам ${ }^{6}$. Эта деталь, почему-то не замеченная исследователями, читавшими дело прежде, объясняет серьёзные сложности, с которыми Жолтовский столкнулся в начале своей профессиональной карьеры. Вплоть до присуждения ему звания академика архитектуры в ноябре 1909 года Жолтовский не имел формального права на производство построек, поэтому на протяжение целого десятилетия по выходе из Академии подвизался в сфере проектирования интерьеров, а если строил, то по частному заказу и за чертой города Москвы.

Родившийся под Пинском, окончивший реальное училище в Астрахани, проживший после этого около года в Риге и отучившийся в петербургской Академии, Жолтовский в 1900 году обосновался в Москве, где и прожил до конца своих дней. Есть все основания считать его переезд из столицы вынужденной мерой, тем более что незадолго до отъезда архитектор женился, но супруга за ним не последовала. Имя Жолтовского фигурирует среди специалистов, занимавшихся отделкой здания гостиницы «Метрополь» после ареста С.И. Мамонтова, затеявшего эту грандиозную стройку в 1898 году. Работы на новом этапе курировало Санкт-Петербургское страховое общество, и в состав группы технического надзора под руководством П.Н. Казина (главного строителя) вошли в основном петербуржцы, включая Жолтовского и гражданского инженера С.П. Галензовского ${ }^{7}$, в соавторстве с которым Иван Владиславович прежде участвовал в архитектурных конкурсах и который был шафером на его свадьбе.

Как уже было сказано, диплом архитектора Жолтовский не получил, но накануне отъезда из Петербурга заручился

\footnotetext{
${ }^{1}$ Такая реконструкция была предпринята С.0. Хан-Магомедовым [2, с. 65-67].

2 Уязвимость этого мнения обнаруживается чисто арифметически: в 1917 году И.В. Жолтовскому исполнилось 50 лет, он был значительно старше конструктивистов, участников В0ПРА и всех прочих участников архитектурных баталий рубежа 1920-1930-х годов. Жолтовский сформировался в дореволюционные десятилетия, его творческая траектория была вполне однозначной и не колебалась вслед за политической и иной конъюнктурой.

${ }^{3}$ См. статью Е.Ю. Багиной, посвящённую «белым пятнам» биографии Жолтовского [11]. Большой интерес представляет, например, попытка С.Ю. Кавтарадзе объяснить обширное цитирование Жолтовским конкретного памятника итальянского Ренессанса в московском особняке Тарасова [12] и предпринятый А.Д. Бархиным опыт рассмотрения творчества Жолтовского в широком интернациональном контексте [13].

${ }^{4}$ РГАЛИ. Ф. 2073. 0п. 8. Д. 12. Л. 159-164; Российский национальный музей музыки. Ф. 318. Ед. хр. 1055. Л. 27-29 об.; Перечень важнейших построек и проектов лауреата Сталинской премии заслуженного деятеля науки и искусства академика архитектуры Ивана Владиславовича Жолтовского. - М. : Союз советских архитекторов СССР, 1952. - [6] с., портр.; Академик архитектуры заслуженный деятель науки и искусств Иван Владиславович Жолтовский: Перечень важнейших построек и проектов. - [М.] : Союз архитекторов СССР, 1957. - [7] с., 1 отд. л. портр.

${ }^{5}$ Габричевский А.Г. Иван Владиславович Жолтовский как теоретик архитектуры (опыт характеристики). М., 1946 (источник: РГАЛИ. Ф. 2774.0 Пп. 1. Д. 114. Л. 7).

${ }^{6}$ РГИА. Ф. 789. 0п. 11. 1887 г. Д. 115. Л. 69. Основные биографические сведения из этого архивного дела были опубликованы в статье: [15].

${ }^{7}$ РГИА. Ф. 613. 0п. 1. Д. 110. Л. 47.
} 
бумагой, подтверждавшей его квалификацию как учителя рисования в средних учебных заведениях. По приезде в Москву он моментально получил место преподавателя в Строгановском училище, очевидно, по протекции своего однокашника С.В. Ноаковского, который занимал в этом заведении высокопоставленную должность инспектора классов. Поскольку на выправление свидетельства в Академии ушёл почти год (!), разумно полагать, что переезд и трудоустройство по педагогической части планировались Жолтовским заблаговременно (рис. 2).

Дебютом Жолтовского как архитектора-строителя стал павильон Скакового общества. Это произведение заслуживает отдельного разговора, поскольку история его появления до сих пор подробно не изучена, как не прояснено и интригующее превращение викторианской неоготики в неоклассику. Очевидно, что повторяемые из работы в работу слова о руководившем Жолтовским стремлении уйти от англицизмов к патриотическим формам русского ампира [3, с. 6; 16, с. 56] по крайней мере нуждаются в дополнениях. А знакомство $\mathrm{c}$ записными книжками Жолтовского того времени, которые он вёл исключительно на польском языке, никак не позволяет уловить его русскую идентичность или специальный интерес к русской архитектуре ${ }^{8}$.

В процессе реконструкции обстоятельств дореволюционного этапа биографии Жолтовского, удалось внести уточнения и дополнения в список его работ. Ни в один из перечней не был включён усадебный дом в Щурове близ подмосковной Коломны, хотя архитектор Е.Б. Новикова, племянница его

${ }^{8}$ гнимA Pla 9519.

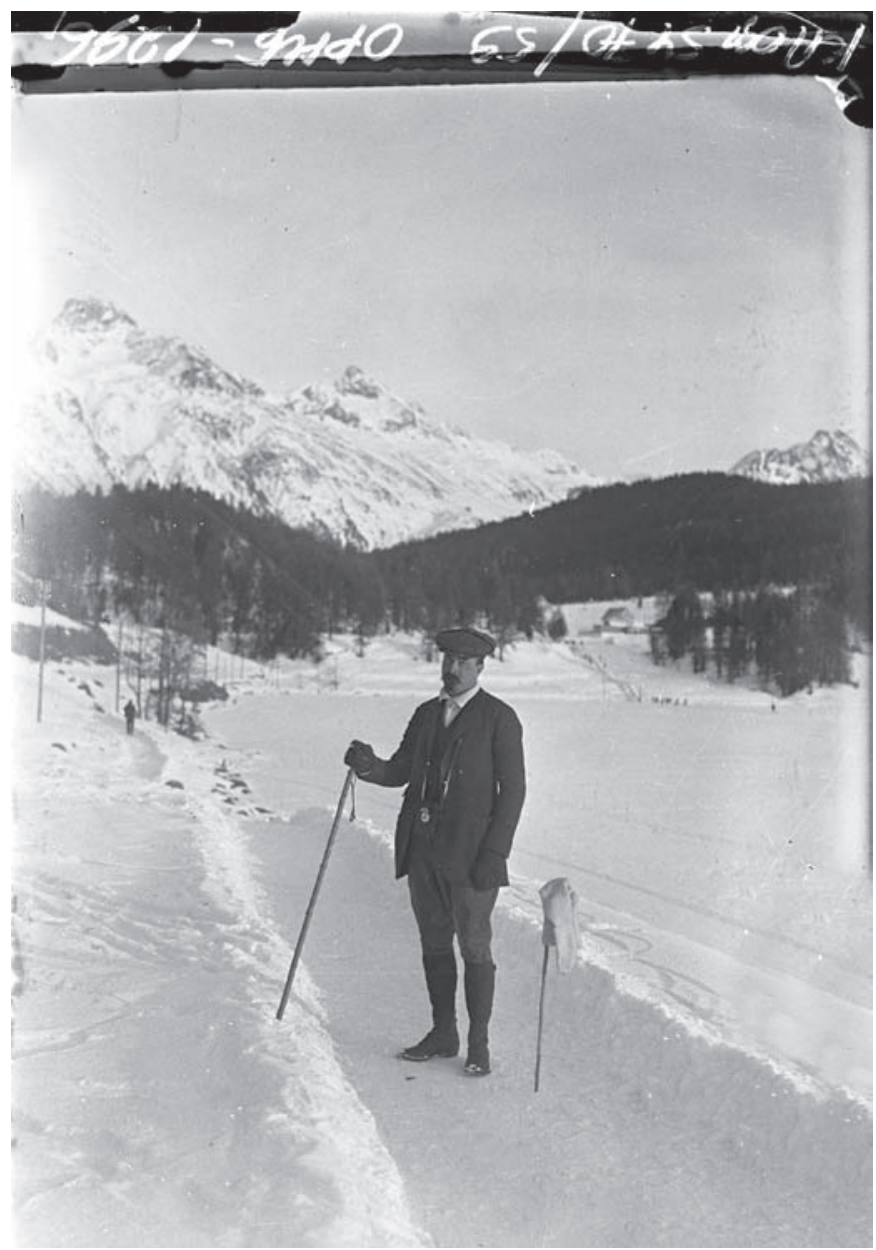

Рис. 2. Портрет И.В. Жолтовского, Швейцария, 1900-е годы (источник: ГНИМА)

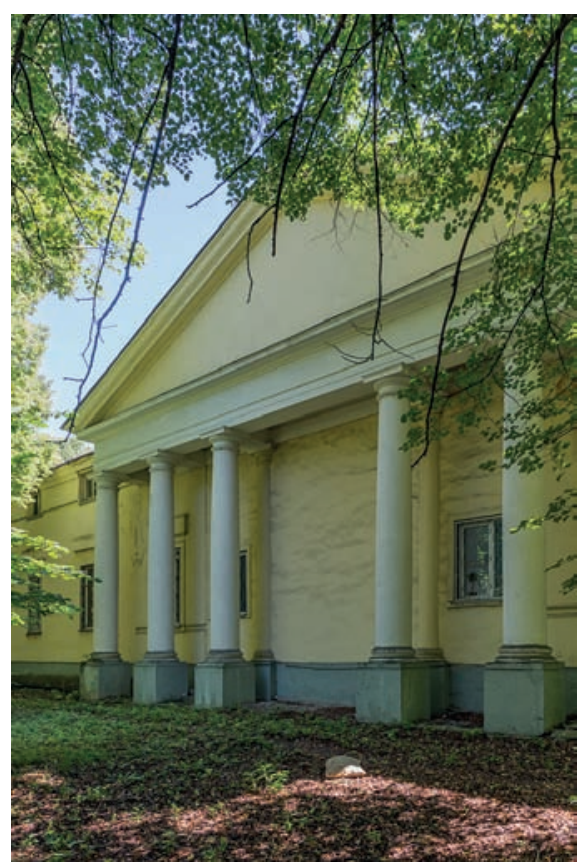

a)

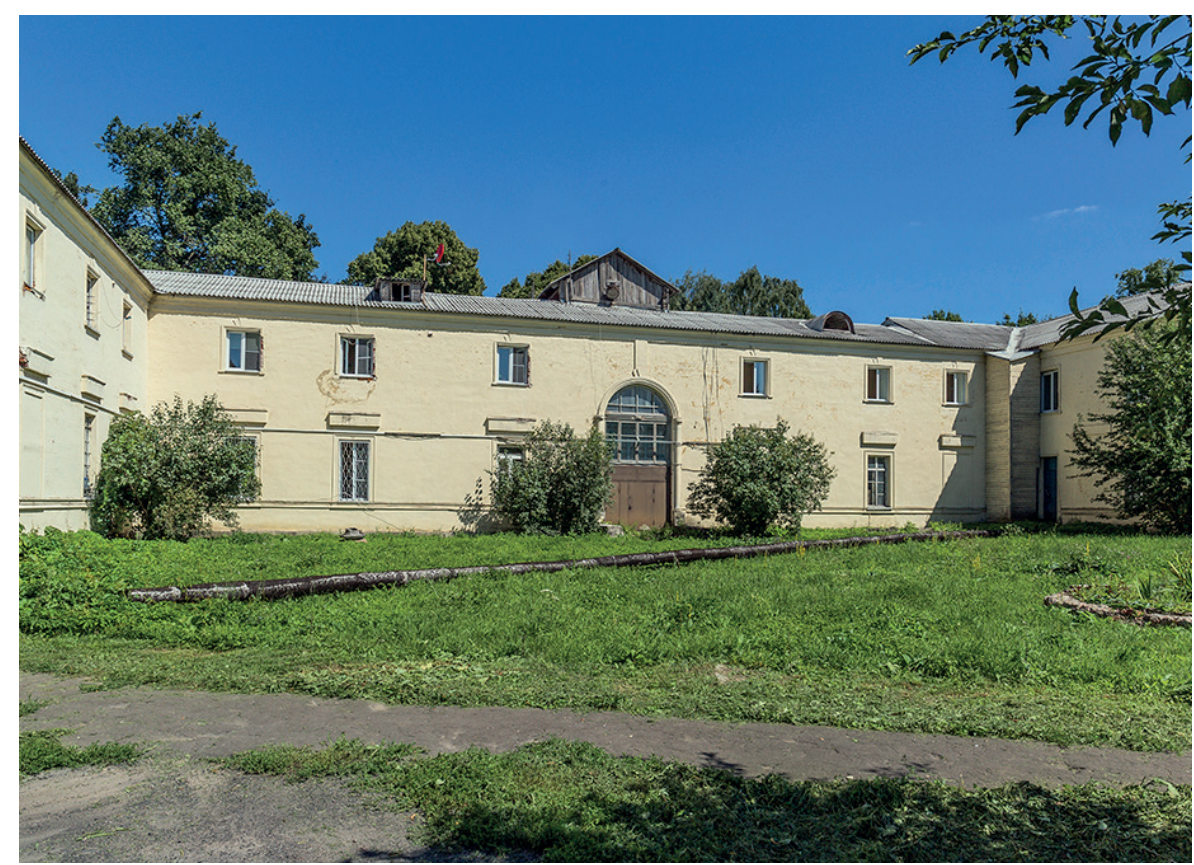

б)

Рис. 3. Усадебный дом в Щурове (ныне в черте города Коломны). Архитектор И.В. Жолтовский. 1900-1910-е годы. Фото А.Н. Яковлева. 2018 год: а) портик заложенного въезда со стороны набережной Оки; б) внутренний вид каре. 
заказчицы К.А. Морозовой, в своих воспоминаниях твёрдо указывает на авторство Ивана Владиславовича [17, с. 152]. Как было показано нами в одной из статей, замысел дома в Щурове (не вполне реализованный) хорошо вписывается в контекст интересов Жолтовского периода работы над павильоном Скакового общества: план здания перекликается с композицией мантуанского палаццо дель Те Дж. Романо, знаменитого «иппическими» мотивами своего внутреннего убранства (герцог Мантуи славился в XVI веке как чуть ли не главный коннозаводчик Европы) [18]. В итоге эта тема не прозвучала в интерьерах Скакового павильона, но отзвуки её присутствуют в других работах Жолтовского. По-видимому, каре щуровского дома на берегу 0ки, столь не типичное для усадебной архитектуры, возникло именно под впечатлением от палаццо дель Те (рис. 3).

Другой эпизод также связан с практически забытой ранней работой Жолтовского. В 1911 году в Риме состоялась Международная художественная выставка, приуроченная к полувековому юбилею объединения Италии. Хорошо известно, что Российскую империю на ней представлял павильон, спроектированный В.А. Щуко. Архивные документы позволили описать предысторию этой архитектурной акции,

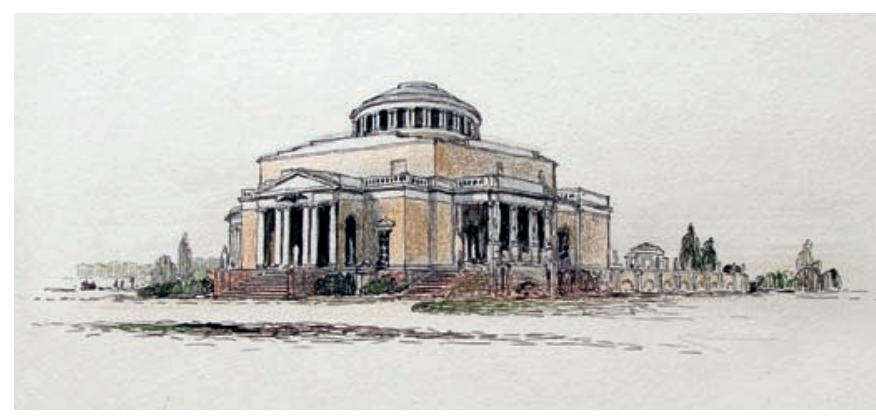

Рис. 4. М.М. Перетяткович. Эскиз павильона Русского отдела на Международной выставке в Риме. Перспектива. 1909-1910 (?) годы (источник: НИМ РАХ) восходящую к 1909 году. Причём одним из её действующих лиц оказался Жолтовский.

Подготовка к участию России в выставке была возложена на Академию художеств. Генеральным комиссаром русского отдела был назначен граф Д.И. Толстой, а его помощником библиотекарь Академии и даровитый график Ф.Г. Беренштам. Он же незадолго до этого активно способствовал избранию Жолтовского в академики архитектуры. Вероятно, Беренштам симпатизировал Ивану Владиславовичу и способствовал тому, чтобы составление проекта павильона в Риме было поручено именно ему. Жолтовский принял предложение генерального комиссара Толстого и даже выехал в Рим вместе с Беренштамом, чтобы на месте приступить к проектированию. Однако уже в марте 1910 года таковое было перепоручено Щуко․ Из архивных дел невозможно понять причину прекращения сотрудничества с Жолтовским и ответить на вопрос о том, успел ли он приступить к работе.

Ответ на этот вопрос обнаружился в Научно-исследовательском музее Российской Академии художеств (НИМ РАХ, (анкт-Петербург), где хранится несколько эскизов павильона для римской выставки, атрибутированных как работы петербуржца М.М. Перетятковича. Поскольку подпись этого архитектора имеется лишь на одном из листов (рис. 4), которые отнюдь не единообразны по манере исполнения, у нас возникло резонное подозрение, что среди данных эскизов могут быть и работы Жолтовского. Сопоставив эскизы из петербургского музея с подписной «Архитектурной фантазией в стиле Палладио» из ГНИМА им. А.В. Щусева, которая экспонировалась на выставке «Палладио в России» в 2015 году, мы пришли к двойному открытию: лист из ГНИМА представляет собой вариант эскиза римского павильона, а поскольку он имеет подпись Жолтовского, то практически идентичный ему по композиции эскиз из НИМ PAX следует атрибутировать его

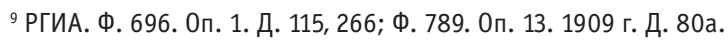

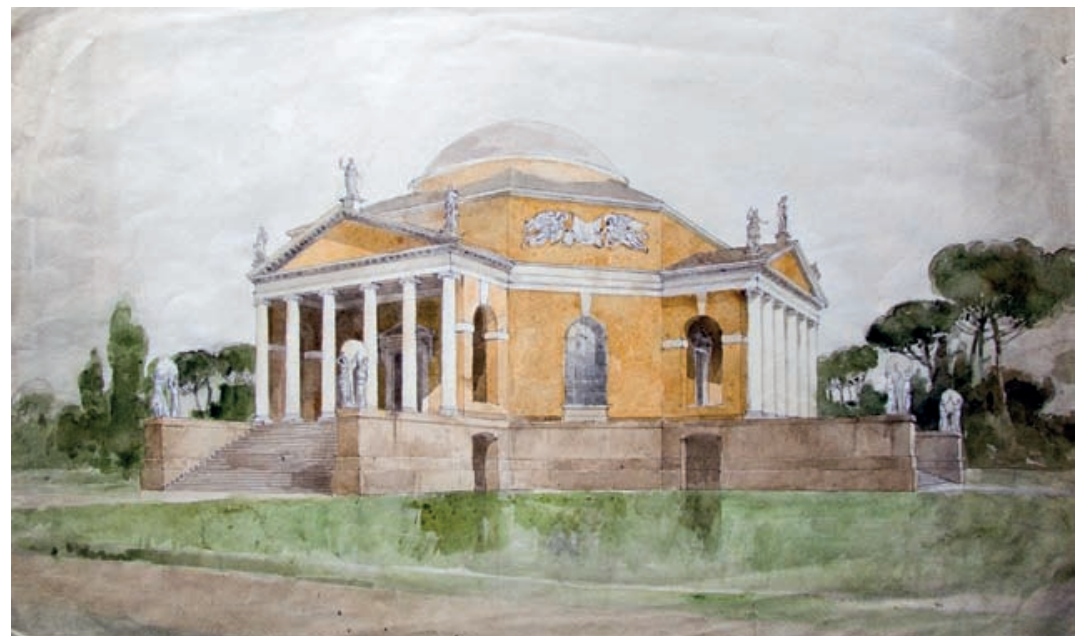

a)

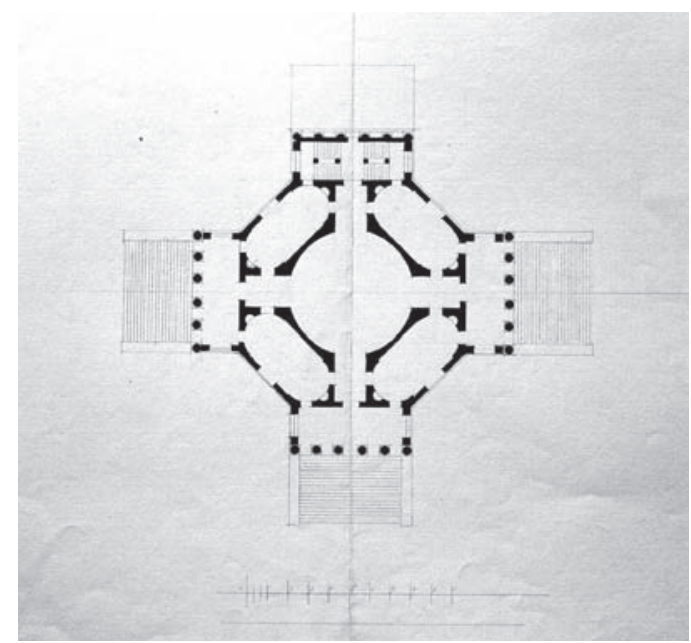

б)

Рис. 5. М.М. Перетяткович (И.В. Жолтовский). Эскиз павильона Русского отдела на Международной выставке в Риме. 1909-1910 годы (источник: НИМ РАХ): а) перспектива; б) план 
же руке (рис. 5). Ещё один петербургский вариант отличается только формой основного объёма - четверик вместо октагона. С большой долей уверенности его также можно считать работой Ивана Владиславовича [19].

Впрочем, верификация, казалось бы, общеизвестных данных о творческом наследии Жолтовского может приводить не только к открытиям новых произведений, но и к опровержению его авторства. Апофеозом карьеры Жолтовского явилось издание перевода самого знаменитого трактата Палладио [20]. В фонде Государственной академии художественных наук (ГАХН) в Российском государственном архиве литературы и искусства (РГАЛИ, Москва) нами были обнаружены фрагменты перевода этого текста, заключённые в одном деле с полным переводом другого сочинения Палладио - «Древности Рима». Этот перевод имеет титульный лист с указанием имени переводчика, даты и места: «Перевод с итальянского Е.П. Рябушинской, 1919 год, Москва». Сравнение приложенных фрагментов перевода «Четырёх

${ }^{10}$ ГНИМА ОФ 5485. Л. 2 об.

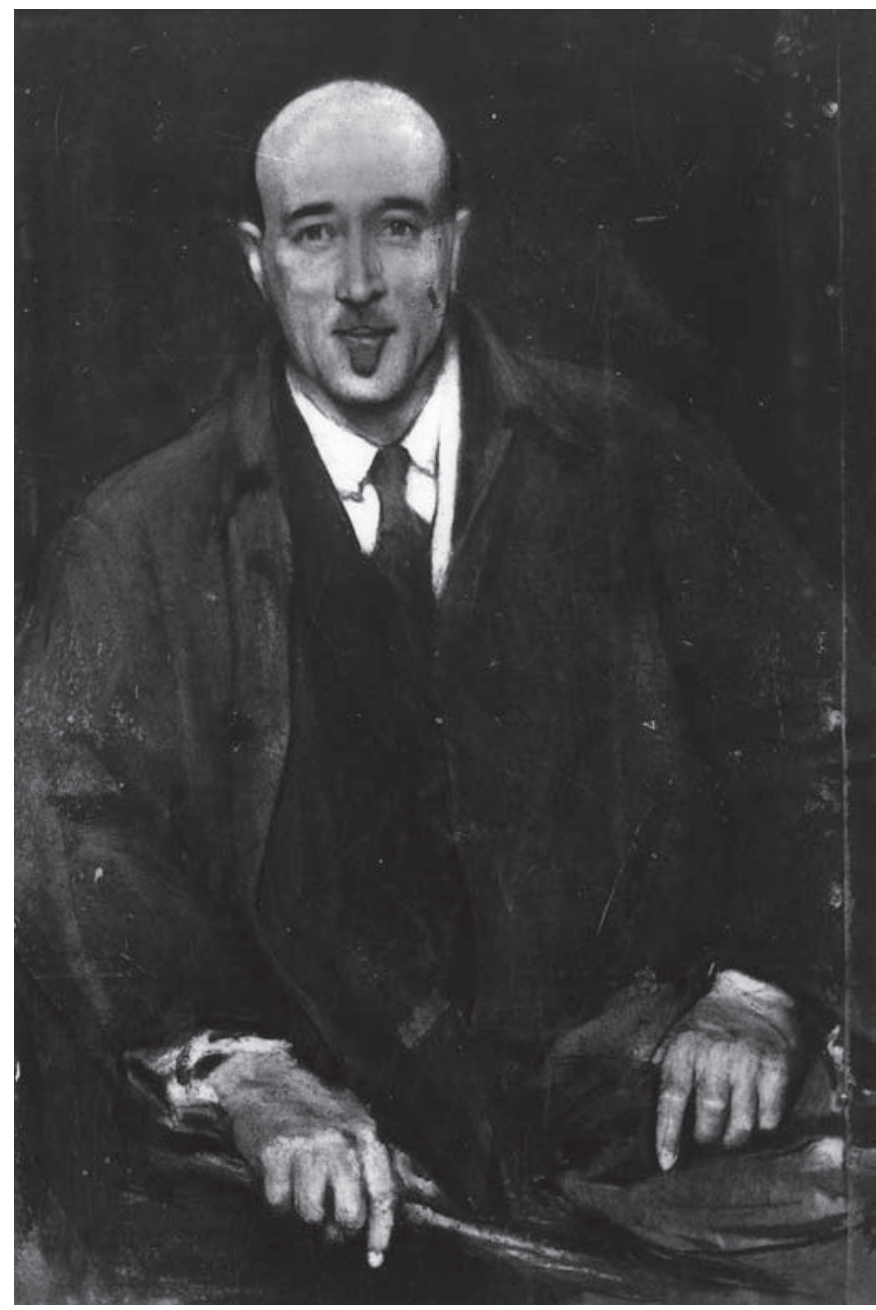

Pис. 6. И.В. Жолтовский в период службы в Наркомпросе (Народном комиссариате просвещения) РСФСР. Фотокопия портрета работы С.В. Малютина. 1919 год (источник: РГАЛИ) книг...» с полным текстом, хранящимся в том же архиве в личном фонде Жолтовского показало полное совпадение. Речь, несомненно, идёт об одном и том же переводе, который был опубликован в 1936 году с небольшими редакторскими правками, внесёнными, надо полагать, А.Г. Габричевским.

Одновременно в архиве ГнИМА им. А.В. Щусева обнаружился фрагмент рукописи перевода с приложением записки-посвящения, автор которой от женского лица сообщает об обстоятельствах своей переводческой работы: «В конце 1918 года И[ван] В[ладиславович] образовал при руководимом им Отделе архитектуры (на самом деле, архитектурном подотделе Отдела И30 Наркомпроса. - авт.) отдел переводов и предложил мне приступить к переводу Palladio, обещая свою помощь и разъяснения в трудных для меня местах. В мае 1919 года перевод был окончен. <...> В главах о мостах мне даны были ценные указания П.В. Щусева, которому приношу свою глубокую благодарность. Главный же вдохновитель и руководитель этого перевода был Иван Владиславович Жолтовский, имя которого, может быть, со временем будет столько же дорого русскому искусству, как для художественного мира имя Palladio» ${ }^{10}$ (рис. 6). Неизвестную, полагаясь на авторизованный перевод из РГАЛИ, можно отождествить с Елизаветой Павловной Рябушинской представительницей знаменитого клана, которую молва называет гражданской женой Жолтовского. А словам её относительно предприятия ведомства А.В. Луначарского по переводу классиков, находится официальное подтверждение в сборнике «Советское искусство за 15 лет» (1933): «Когда был закончен перевод классического трактата по архитектуре - Palladio “Architectura”, - его размножили в четырёх экземплярах и распределили по соответствующим библиотекам» [21, с. 69].

Итак, по итогам предпринятого исследования истории советского перевода Палладио можно со всей определённостью заключить, что Жолтовскому в ней принадлежала роль не автора, а организатора и публикатора [22].

К сожалению, до сих пор остаётся невыясненной судьба личного архива зодчего. Содержимое фондов Жолтовского в РГАЛИ и ГНИМА им. А.В. Щусева характеризуется явной неполнотой. Вполне вероятно, что часть материалов не попала в государственные хранилища. Исходя из этого, нельзя исключать и возможности находок прежде неизвестных документов. В любом случае, дальнейшее исследование творческой биографии И.В. Жолтовского имеет благоприятные перспективы.

\section{Лumepamypa}

1. Каверин, В.А. Эпилог : Мемуары / В.А Каверин. - М. : Московский рабочий, 1989. - 538 с. ISBN 5-239-00642-3

2. Хан-Магомедов, С.О. Архитектура советского авангарда: в 2 кн. Кн. 1: Проблемы формообразования. Мастера и течения. - М. : Стройиздат, 1996. -709 с. ISBN 5-274-02045-3 
3. И.В. Жолтовский: проекты и постройки / Вступ. статья Г.Д. Ощепкова. - М. : Государственное издательство по строительству и архитектуре, 1955. - 157 с.

4. Фирсова, А.В. Творческое наследие И.В. Жолтовского в отечественной архитектуре XX века : диссертация ... кандидата искусствоведения. - М., 2004. - 278 с.

5. Хан-Магомедов, С.О. Иван Жолтовский / С.0. ХанМагомедов. - М. : С.Э. Гордеев, 2010. - 352 с.

6. Хмельницкий, Д.С. Иван Жолтовский. Архитектор советского палладианства / Д.С. Хмельницкий; при уч. А.В. Фирсовой. - Берлин: D0M publishers, 2015. - 211 с.

7. Нащокина, М.В. Русская усадьба Серебряного века / М.В. Нащокина. - М. : Улей, 2007. - 631 с.

8. Нащокина, М.В. Усадьба Лубенькино - малоизвестная работа И.В. Жолтовского / М.В. Нащокина // Архитектурное наследство. - 2011. - Вып. 55. - С. 317-323.

9. Нащокина, М.В. Жизнь и судьба Ивана Жолтовского / М.В. Нащокина // Academia. Архитектура и строительство. 2018. - № 1. - С. 116-121.

10. Швидковский, Д.О. Иван Владиславович Жолтовский. К 150-летию со дня рождения / Д.0. Швидковский // Academia. Архитектура и строительство. - 2017. - № 4. - С. 5-9.

11. Багина, Е.Ю. Три жизни Ивана Владиславовича Жолтовского / Е.Ю. Багина // Проект Байкал. - 2019. - № 59. - С. 90-98.

12. Кавтарадзе, С.Ю. Мир как шедевр. 0 стилевой принадлежности особняка Тарасова в Москве / С.Ю. Кавтарадзе // Искусствознание. - 2017. - № 4. - С. 28-47.

13. Бархин А.Д. Актуальное, ретроспективное и уникальное в творчестве И.В. Жолтовского 1930-1950-х годов / А.Д. Бархин // Academia. Архитектура и строительство. - 2015. - № 4. - С. 23-31.

14. Печёнкин, И.Е. Архитектор Иван Жолтовский. Эпизоды из ненаписанной биографии / И.Е. Печёнкин, О.С. Шурыгина. - M., 2017. - 160 с.

15. Шурыгина, О.С. Новые данные о И.В. Жолтовском (1867-1959)/ 0.С. Шурыгина // Архитектурное наследство. 2017. - Вып. 67. - С. 170-188.

16. Ревзин, Г.И. Неоклассицизм в русской архитектуре начала XX века / Г.И. Ревзин. - М., НИИТАГ, 1992. - 169 с.

17. Новикова, Е.Б. Хроника пяти поколений. Хлудовы, Найдёновы, Новиковы... / Е.Б. Новикова. - М., 1998. - 318 с.

18. Печёнкин, И.Е. Дом в усадьбе Щурово Морозовых малоизвестная работа И.В. Жолтовского // И.Е. Печёнкин, 0.С. Шурыгина // Русская усадьба : Сборник Общества изучения русской усадьбы / науч. ред.-сост. М.В. Нащокина. - СПб. : Коло, 2019. - Вып. 25 (41). - С. 153-165.

19. Печёнкин, И.Е. Выставочные павильоны И.В. Жолтовского. К творческой биографии зодчего / И.Е. Печёнкин, О.С. Шурыгина // Архитектурное наследство / гл. ред. и сост. И.А. Бондаренко. - 2019. - Вып. 71. - С. 236-247.

20. Палладио, А. Четыре книги об архитектуре, в коих после краткого трактата о пяти ордерах и наставлении, наиболее необходимых для строительства, трактуется о частных домах, дорогах, мостах, площадях, ксистах и храмах : В 2 т. Т. 1. Текст трактата / пер. И.В. Жолтовского. - М. : Издательство Всесоюзной Академии архитектуры, 1936. - 345 с.

21. Советское искусство за 15 лет: Материалы и документация / под ред. с вводными статьями и примеч. И. Маца; сост. И. Маца, Л. Рейнгард и Л. Ремпель. - М., Л. : ОГИЗ-ИЗОГИЗ, 1933. - 664 с., 16 вкл. л. красочных ил.

22. Печёнкин, И.Е. Палладио по-русски. Новые данные о переводе «Четырёх книг об архитектуре» в начале XX века / И.Е. Печёнкин, О.С. Шурыгина. // Искусствознание. - 2018. - № 3. - С. 238-263.

\section{References}

1. Kaverin V.A. Epilog [The Epilogue]. Moscow, Moskovskij rabochij Publ., 1989, 538 p. ISBN 5-239-00642-3

2. Khan-Magomedov S.0. Arhitektura sovetskogo avangarda : v 2 kn. Kn. 1: Problemy formoobrazovaniya. Mastera i techeniya [Architecture of the Soviet avant-garde: vol. 1: Problems of the morphogenesis. Architects and trends]. Moscow, Strojizdat Publ., 1996. (In Russ.)

3. I.V. Zholtovskii: proekty i postroiki [I.V. Zholtovsky: projects and buildings], G.D. Oschepkov (ntroductory article). Moscow, State Publishing House for Construction and Architecture Publ., 1955, 157 p. (In Russ.)

4. Firsova A.V. Tvorcheskoe nasledie I.V. Zholtovskogo v otechestvennoj arhitekture XX veka: Diss. na soiskanie uchjonoj stepeni kandidata iskusstvovedenija [I.V. Zholtovsky's Creative Heritage in XX century Russian Architecture. Ph.D. dissertation], 2 vol., Moscow, 2004, 278 p.

5. Khan-Magomedov S.0. Ivan Zholtovskij [Ivan Zholtovsky]. Moscow, S.Je. Gordeev Publ., 2010, 352 p. (In Russ.)

6. Khmelnizky D.S., Firsova A.V. Ivan Zholtovskij. Arhitektor sovetskogo palladianstva [Ivan Zholtovsky, an architect of Soviet Palladianism]. Berlin, DOM publishers, 2015. - 211 p. (In Germ., in Russ.)

7. Nashchokina M.V. Russkaya usad'ba Serebryanogo veka [Russian Manor in the Silver Age]. Moscow, Ulej Publ., 2007. - 631 p. (In Russ.)

8. Nashchokina M.V. Usad'ba Luben'kino - maloizvestnaya rabota I.V. Zholtovskogo [Lubenkino Manor: a littleknown opus of I.V. Zholtovsky]. In: I.A. Bondarenko (ed.) Arhitekturnoe nasledstvo [Architectural heritage], 2011, vol. 55, pp. 317-323.

9. Nashchokina M.V. Zhizn' i sud'ba Ivana Zholtovskogo [The Life and Fate of Ivan Zholtovsky]. In: Academia. Arhitektura $i$ stroitel'stvo [Academia. Architecture and Construction], 2018, no 1, pp. 116-121 (In Russ., abstr. in Engl.)

10. Shvidkovsky D.0. Ivan Vladislavovich Zholtovskij. K 150-letiyu so dnya rozhdeniya [Ivan Vladislavovich Zholtovsky: on the Occasion of the 150th Anniversary of His Birth]. In: Academia. Arkhitektura i stroitel'stvo [Academia. Architecture and Construction], 2017, no. 4, pp. 5-9. (In Russ., abstr. in Engl.) 
11. Bagina E.Yu. Tri zhizni Ivana Vladislavovicha Zholtovskogo [Threelives of Ivan Vladislavovich Zholtovsky]. In: Proekt Bajkal [Project Baikal], 2019, no. 59, pp. 90-98. (In Russ., abstr. in Engl.)

12. Kavtaradze S.Yu. Mir kak shedevr. 0 stilevoj prinadlezhnosti osobnyaka Tarasova v Moskve [The World as a Masterpiece: About Style of Tarasov Mansion in Moscow]. In: Iskusstvoznanie [Art Studies Magazine], 2017, no. 4, pp. 28-47. (In Russ.)

13. Barhin A. Aktual'noe, retrospektivnoe $i$ unikal'noe $v$ tvorchestve I.V. Zholtovskogo 1930-1950-h godov [Actual, Retrospective and Unique in I.V. Zholtovsky's Creative Practice of 1930-1950th]. In: Academia. Arkhitektura i stroitel'stvo [Academia. Architecture and Construction], 2015, no. 4, pp. 23-31. (In Russ., abstr. in Engl.)

14. Pechenkin I.E.; Shurygina O.S. Arhitektor Ivan Zholtovskij. Jepizody iz nenapisannoj biografii [Architect Ivan Zholtovsky. The episodes of artistic biography]. Moscow, 2017, 160 p. (In Russ.)

15. Shurygina O.S. Novye dannye o I.V. Zholtovskom (1867-1959) [The new intelligence about I.V. Zholtovsky]. In: I.A. Bondarenko (ed) Arhitekturnoe nasledstvo [Architectural heritage], 2017, vol. 67, pp. 170-188. (In Russ.)

16. Revzin G.I. Neoklassitsizm v russkoi arkhitekture nachala $X X$ veka [Neoclassicism in Russian architecture in the beginning of 20th Century]. Moscow, NIITAG Publ., 1992, 169 p. (In Russ.)

17. Novikova E.B. Hronika pyati pokolenij. Hludovy, Najdyonovy, Novikovy... [A Chronicle of the five generations: the Khludovs, the Naidyonovs, the Novikovs...]. Moscow, 1998, 318 p.

18. Pechenkin I.E.; Shurygina 0.S. Dom v usad'be Shchurovo Morozovyh - maloizvestnaja rabota I.V. Zholtovskogo [Manor
House in Shchurovo of Morozovs, the little-known opus of Ivan Zholtovsky]. In: M.V. Nashchokina (scientific. ed.-comp) Russkaya usad'ba : Sbornik Obshchestva izucheniya russkoi usad'by [Russian Estate: Collection of the Society for the Study of the Russian Estate], Iss. 25 (41). Saint Petersburg, Kolo Publ., 2019, pp. 153-165.

19. Pechenkin I.E.; Shurygina O.S. Vystavochnye pavil'ony I.V.Zholtovskogo. K tvorcheskoj biografii zodchego [Exhibition pavilions of I.V. Zholtovsky: To description of architect's biography]. In: I.A. Bondarenko (ed.) Arhitekturnoe nasledstvo [Architectural heritage], 2019, vol. 71, pp. 236-247.

20. Palladio, Andrea. Chetyre knigi ob arhitekture, $v$ koih posle kratkogo traktata o pyati orderah i nastavlenii, naibolee neobhodimyh dlya stroitel'stva, traktuetsya o chastnyh domah, dorogah, mostah, ploshchadyah, ksistah i hramah : V 2 t. T. 1. Tekst traktata, per. I.V. Zholtovskogo [The Four Books on Architecture: in 2 volumes. Vol. 1: The text of the treatise (translated by I.V. Zholtovsky)]. Moscow, Publishing House of the All-Union Academy of Architecture., 1936, 345 p.

21. Sovetskoe iskusstvo za 15let: Materialy i dokumentaciya, pod red. s vvodnymi stat'yami i primech. I. Maca; sost. I. Maca, L. Rejngard i L. Rempel' In Maza, I (ed.) Soviet art through the fifteen years: the materials and documents]. Moscow; Leningrad, OGIZ-IZOGIZ Publ., 1933, 664 p.

22. Pechenkin I.E.; Shurygina O.S. Palladio po-russki. Novye dannye o perevode «Chetyrjoh knig ob arhitekture» v nachale XX veka [Palladio in Russian. New information about the Russian Translation of "The Four Books on Architecture"]. In Iskusstvoznanie [Art Studies Magazine], 2018, no. 3, pp. 238-263.

Печёнкин Илья Евгеньевич (Москва). Кандидат искусствоведения, доцент. Заведующий кафедрой истории русского искусства факультета истории искусства РГГУ, старший научный сотрудник Научно-исследовательского института теории и истории архитектуры и градостроительства (филиал ФГБУ «ЦНИИП Минстроя России») (111024, Москва, ул. Душинская, 9. НИИТИАГ). Эл. почта:pech_archistory@mail.ru.

Шурыгина 0льга Сергеевна (Москва), независимый исследователь, член ICOMOS. Эл. почта: olia85@list.ru.

Pechenkin Ilya E. (Moscow). Candidate of Art History, Associate Professor. Head of the Department of Russian Art History at the Faculty of Art History of Russian State University, Senior Researcher at the Research Institute of Theory and History of Architecture and Urban Planning (9 Dushinskaya st., Moscow, 111024. NIITIAG), branch of the Central Institute for Research and Design of the Ministry of Construction and Housing and Communal Services of the Russian Federation (TsNIIP).E-mail: pech_archistory@mail.ru.

Shurygina Olga S. (Moscow), Independent Researcher, Member of ICOMOS. E-mail: olia85@list.ru. 